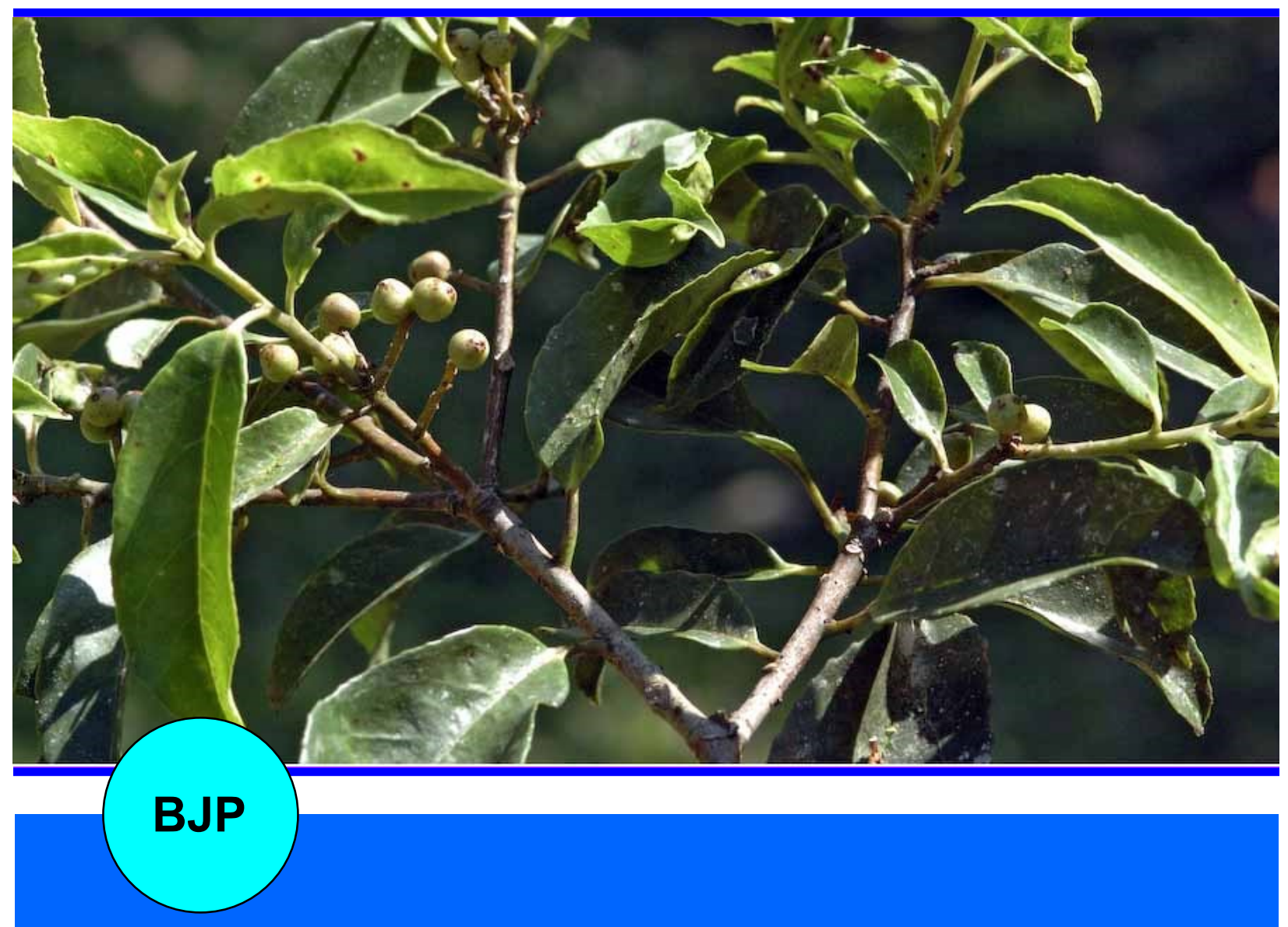

Bangladesh Journal of Pharmacology

Research Article

In vitro and In vivo anti-inflammatory activity of leaves of Symplocos cochinchinensis (Lour) Moore ssp laurina 


\section{In vitro and In vivo anti-inflammatory activity of leaves of Symplocos cochinchinensis (Lour) Moore ssp laurina}

\section{Rajendran Vadivu ${ }^{1}$ and K.S. Lakshmi ${ }^{2}$}

${ }^{1}$ Department of Pharmacognosy, Madras Medical College, Chennai 03, India; ${ }^{2}$ S.R.M. College of Pharmacy, Chennai, Tamilnadu, India.

\begin{tabular}{|c|c|}
\hline \multicolumn{2}{|l|}{ Article Info } \\
\hline Received: & $8 \mathrm{Ju}$ \\
\hline Accepted: & $28 \mathrm{Ju}$ \\
\hline Available Online: & 1 August 200 \\
\hline \multicolumn{2}{|c|}{ DOI: 10.3329/bjp.v3i2.956 } \\
\hline \multicolumn{2}{|c|}{$\begin{array}{l}\text { Cite this article: } \\
\text { Vadivu R, Lakshmi KS. In vitro and In } \\
\text { vivo anti-inflammatory activity of } \\
\text { leaves of Symplocos cochinchinensis } \\
\text { (Lour) Moore ssp laurina. Bangladesh } \\
\text { J Pharmacol. 2008; 3: 121-24. }\end{array}$} \\
\hline
\end{tabular}

\section{Abstract}

The anti-inflammatory activities of different extracts of leaves Symplocos cochinchinensis Lour ssp laurina (Symplococaceae) were investigated for in vitro anti-inflammatory activity by human red blood cell membrane stabilization method. The methanol extract showed effective in vitro anti-inflammatory activity was screened for in vivo anti-inflammatory activity by carrageenan-induced paw edema in rat model. The potency of the extracts was compared with standard diclofenac $(50 \mathrm{mg} / \mathrm{kg})$. The methanol extract showed significant membrane stabilizing action on human red blood cell membrane and reduction of edema in carrageenan induced rat paw edema model.

\section{Introduction}

Symplocos cochinchinensis Lour ssp laurina (Symplococaceae) otherwise known as kablivetti or Lodh tree is widely distributed in tropical, subtropical areas in Asia, Oceania and America. It is widely used in the treatment of various disorders like leprosy, tumors, diarrhea, dysentery, menorrhagia, inflammation and uterine disorders (Ali et al., 1990). Recently much attention have been paid for Symplocos species due to their diverse biological activity in treating various disorders like anti-HIV (Ishida et al., 2001), inhibitory activities against phosphodiesterase (Ahmad et al., 2003) and antitumor (Li et al., 2003) applications.

The inflammatory response involves a complex array of enzyme activation, mediator release, fluid extravasations, cell migration, tissue breakdown and repair (Vane et al., 1995) which are aimed at host defense and usually activated in most disease condition. Currently much interest have been paid in the searching of medicinal plants with anti-inflammatory activity which may lead to the discovery of new therapeutic agent that is not only used to suppress the inflammation but also used in diverse disease conditions where the inflammation response in amplifying the disease process. In this work the various extracts of $S$. cochinchnensis were studied for its in vitro and in vivo anti-inflammatory activities.

\section{Materials and Methods}

The fresh leaves of $S$. cochinchinensis were collected from Ooty in the month of August and it was authenticated by Prof. J. Jayaraman, Taxonomist, PARC, Chennai. A voucher specimen is deposited in the department for the 
future reference. The collected leaves were shade dried and coarsely powdered. The coarse powder was subjected to continuous extraction in a soxhlet apparatus using n-hexane, chloroform, ethyl acetate and methanol as solvents. The solvents were distilled under reduced pressure using rotary vacuum evaporator. The extracts were dissolved in distilled water using 1\% CMC as suspending agent.

\section{Animals}

Wister male albino rats weighing 150-200 g were used for the in vivo anti-inflammatory studies. The animals were housed under standard conditions of temperature $\left(23 \pm 1^{\circ} \mathrm{C}\right), 12$ hours light/dark cycle and fed with water ad libitium. Before performing the experiment the ethical clearance was obtained from institutional animal ethics committee.

In vitro anti-inflammatory activity (Gandhisan et al., 1991): The human red blood cell membrane stabilization method was used for this study. The blood was collected from healthy human volunteer who was not taken any NSAIDS for 2 weeks prior to the experiment and mixed with equal volume of Alsever solution ( $2 \%$ dextrose, $0.8 \%$ sodium citrate, $0.5 \%$ citric acid and $0.4 \%$ $\mathrm{NaCl}$ ) and centrifuged at 3,000 rpm. The packed cells were washed with isosaline and a 10\% suspension was made. Various concentrations of extracts were prepared $(250,500$ and $1,000 \mathrm{mcg} /$ $\mathrm{mL}$ ) using distilled water and to each concentration $1 \mathrm{~mL}$ of phosphate buffer, $2 \mathrm{~mL}$ hyposaline and $0.5 \mathrm{~mL}$ of $\mathrm{HRBC}$ suspension were added. It is incubated at $37^{\circ} \mathrm{C}$ for $30 \mathrm{~min}$ and centrifuged at $3,000 \mathrm{rpm}$ for $20 \mathrm{~min}$. the hemoglobin content of the supernatant solution was estimated spectrophotometrically at $560 \mathrm{~nm}$. Diclofenac $(50 \mathrm{mcg} / \mathrm{mL})$ was used as reference standard and a control was prepared omitting the extracts.

\section{Acute toxicity studies (Ecobichon, 1987)}

Acute toxicity study was carried out for methanol extract using Acute Toxic Class Method as described in OECD [Organization of Economic Co-operation and Development] Guidelines No. 423. The methanol extract was safe up to a dose of $2,000 \mathrm{mg} / \mathrm{kg}$ body weight so $200 \mathrm{mg} / \mathrm{kg}$ and $400 \mathrm{mg} / \mathrm{kg}$ were used as moderate dose for the evaluation.

\section{In vivo anti-inflammatory activity (Winter et al., 1962)}

In vivo anti-inflammatory activity was studied for the methanolic extract by carrageenan induced paw edema model in rats. The Wister albino rats were divided in to 4 groups of 6 animals each. Group I: served as control, Group II, III: received methanol extract at the dose of 200 and $400 \mathrm{mg} / \mathrm{kg}$ and Group IV was served as standard (diclofenac $50 \mathrm{mg} / \mathrm{kg}$ ). Carrageenan was injected in to the sub planter aponeurosis of the right hind paw of rats. An hour before carrageenan injection the animals were given with the extract, standard orally. The paw volumes were measured before and three hours after carrageenan administration by volume displacement method.

\section{Statistical analysis}

The data's were expressed as mean \pm SEM, statistical analysis was performed by one-way ANOVA followed by Tukey-Kramer multiple comparison test, $\mathrm{p}$ values $<0.05$ were considered as significant. Highest significant difference test performed with GraphPad instat software.

\section{Results and Discussion}

The $n$-hexane, chloroform, ethyl acetate and methanolic extracts of the leaves of $S$. cochinchinensis were studied for in vitro antiinflammatory activity by HRBC membrane stabilization method. Among all the extracts methanolic extract showed significant antiinflammatory activity in a concentration dependent manner. Methanol extract at a concentration of $1,000 \mathrm{mcg} / \mathrm{ml}$ showed $67 \%$ protection of HRBC in hypotonic solution. All the results were compared with standard diclofenac which showed $74 \%$ protection.

The extracts exhibited membrane stabilization effect by inhibiting hypotonicity induced lyses of erythrocyte membrane. The erythrocyte membrane is analogous to the lysosomal membrane (Chou, 1997) and its stabilization implies that the extract may as well stabilize lysosomal membranes. Stabilization of lysosomal membrane is important in limiting the 
Table I

\begin{tabular}{|c|c|c|c|}
\hline \multicolumn{4}{|c|}{$\begin{array}{l}\text { In vitro anti inflammatory activity of methanolic } \\
\text { extract of symplocos cochinchinensis by HRBC } \\
\text { membrane stabilization method }\end{array}$} \\
\hline Treatment & $\begin{array}{c}\text { Conc } \\
(\mathrm{mcg} / \mathrm{mL})\end{array}$ & $\begin{array}{c}\text { Absorbance } \\
(540 \mathrm{~nm})\end{array}$ & $\begin{array}{c}\% \\
\text { Inhibition }\end{array}$ \\
\hline Control & -- & $0.48 \pm 0.012$ & -- \\
\hline \multirow[t]{3}{*}{$n$-Hexane } & 1,000 & $0.35 \pm 0.03^{b}$ & 28.6 \\
\hline & 500 & $0.36 \pm 0.0^{b}$ & 25.8 \\
\hline & 250 & $0.38 \pm 0.005$ & 23.4 \\
\hline \multirow[t]{3}{*}{ Chloroform } & 1,000 & $0.34 \pm 0.003^{a}$ & 31.0 \\
\hline & 500 & $0.33 \pm 0.04^{a}$ & 30.0 \\
\hline & 250 & $0.35 \pm 0.005^{\mathrm{a}}$ & 26.5 \\
\hline \multirow[t]{3}{*}{ Ethyl acetate } & 1,000 & $0.25 \pm 0.001^{\mathrm{a}}$ & 47.3 \\
\hline & 500 & $0.28 \pm 0.007^{a}$ & 43.1 \\
\hline & 25 & $0.29 \pm 0.005^{a}$ & 40.2 \\
\hline \multirow[t]{3}{*}{ Methanol } & 1,000 & $0.15 \pm 0.001^{\mathrm{a}}$ & 69.9 \\
\hline & 500 & $0.19 \pm 0.002^{\mathrm{a}}$ & 60.5 \\
\hline & 250 & $0.20 \pm 0.001$ & 58.1 \\
\hline Diclofenac & 50 & $0.13 \pm 0.002^{\mathrm{a}}$ & 73.9 \\
\hline
\end{tabular}

Values are expressed as mean \pm SEM. $n=6$ animals in each group. ${ }^{a} \mathrm{p}<0.001 ;{ }^{b} \mathrm{p}<0.01$ compared to control group

Table II

In vivo anti inflammatory activity of methanolic extract of Symplocos cochinchinensis on caarageenin- induced paw edema in rats

\begin{tabular}{|lccc|}
\hline Treatment & $\begin{array}{c}\text { Dose } \\
(\mathrm{mg} / \mathrm{kg})\end{array}$ & $\begin{array}{c}\text { Edema volume } \\
(\mathrm{mL})\end{array}$ & $\begin{array}{c}\text { \% Inhi- } \\
\text { bition }\end{array}$ \\
\hline $\begin{array}{l}\text { Control } \\
\begin{array}{l}\text { Methanolic } \\
\text { extract }\end{array}\end{array}$ & -- & $0.72 \pm 0.020$ & -- \\
$\begin{array}{l}\text { Methanolic } \\
\text { extract }\end{array}$ & 400 & $0.48 \pm 0.029 \mathrm{a}$ & 33.3 \\
$\begin{array}{l}\text { Diclofenac } \\
\begin{array}{l}\text { Values are expressed as mean } \pm \text { SEM. } \mathrm{n}=6 \text { animals in } \\
\text { each group. ap<0.001 compared to control group }\end{array}\end{array}$ \\
\hline
\end{tabular}

inflammatory response by preventing the release of lysosomal constituents of activated neutrophil such as bactericidal enzymes and proteases, which cause further tissue inflammation and damage upon extra cellular release (Murugasan, 1981). Some of the NSAIDs are known to posses membrane stabilization properties which may contribute to the potency of their antiinflammatory effect. Though the exact mechanism of the membrane stabilization by the extract is not known yet, hypotonicity-induced hemolysis may arise from shrinkage of the cells due to osmotic loss of intracellular electrolyte and fluid components. The extract may inhibit the processes, which may stimulate or enhance the efflux of these intracellular components (Iwueke, 2006).

Since methanol extract showed significant invitro anti-inflammatory activity it was selected for the evaluation of in vivo anti-inflammatory activity by carrageenan induced paw edema model in rats. The extract showed significant anti-inflammatory activity (53\%) at the dose of $400 \mathrm{mg} / \mathrm{ml}$ while the standard diclofenac showed $75 \%$ inhibition of edema. On the basis of the above results it can be concluded that the methanol extract posses significant antiinflammatory activity studied by in vitro and in vivo models. The study also provides a strong evidence for the use of the leaves $S$. cochinchinensis in folkloric treatment as antiinflammatory agent. The activity may be due to the presence of one or more phytochemical constituents present in the extract further study is warranted, for isolation of the constituents responsible for the activity and also to explore the exact mechanism of action of the activity.

\section{References}

Ali M, Bhutani KK, Srivastava TN. Triterpenoids from Symplocos racemosa bark. Phytochemistry 1990; 29: 3601-04. http:/ / dx.doi.org/10.1016/0031- 9422(90)85284-M

Ahmad VU, Abbasi MA, Hussain H, Akhtar MN, Farooq U, Choudhary MI. Phenolic glycoside from Symplocos racemosa natural inhibitors of phosphodiesterase I. Phytochemistry 2003; 63: 217-20. http://dx.doi.org/10.1016/S0031-9422(03) 00075-X (PMid:12711144)

Chou CT. The anti-inflammatory effect of Tripterygium wilfordii Hook F on adjuvant-induced paw edema in rats and inflammatory mediators release. Phytother Res. 1997; 11: 152 -54. http://dx.doi.org/10.1002/(SICI)1099-1573(199703) 11:2\%3c152::AID-PTR45\%3e3.0.CO;2-L

Ecobichon DJ. The basis of toxicology testing. 2nd ed. New York, CRC Press, 1997, pp 43-60.

Gandhisan R, Thamaraichelvan A, Baburaj. Anti-inflammatory action of Lannea coromandelica Hrbc membrane stabilization. Fitotherapia 1991; 62: 82-83.

Ishida J, Wang HK, Oyama M, Cosentino ML, Hu CQ, Lee KH. Anti-AIDS agent. 46 Anti HIV activity of Harman and antiHIV principle from Symplocos setchuensis and its derivatives. J Nat Prod. 2001; 64: 958-60. http://dx.doi.org/10.1021/ np0101189 (PMid:11473435) 
Iwueke AV, Nwodo OF, Okoli CO. Evaluation of the antiinflammatory and analgesic activities of Vitex doinana leaves. African J Biotech. 2006; 5: 1929-35.

Li XH, Shen DD, Li N, Yu SS. Bioactive terpenoids from Symplocs chinensis. A. Asian Nat Prod Res. 2003; 5: 49-56. http://dx.doi.org/10.1080/1028602031000080469 (PMid:12608639)

Murugasan N, Vember S, Damodharan C. Studies on erythrocyte membrane IV: In vitro hemolytic activity of oleander extract. Toxicol Lett. 1981; 8: 33-38. http:// dx.doi.org/10.1016/0378-4274(81)90134-X (PMid:7195617)

Vane JR, Botting RM. New insight into the mode of action of anti-inflammatory drugs. Inflamm Res. 1995; 44: 1-10. http://dx.doi.org/10.1007/ BF01630479 (PMid:7664022)

Winter CA, Risley EA, Nuss GW. Carrageenan-induced edema in hind paw of the rat as an assay for anti-inflammatory drugs. Proc Soc Expt Biol Med. 1962; 111: 44-47. 